\title{
The Natural Rate of Interest in Brazil between 1999 and 2005*
}

\section{Paulo Chananeco F. de Barcellos Neto ${ }^{\dagger}$, Marcelo Savino Portugal ${ }^{\ddagger}$}

\author{
Contents: 1. Introduction; 2. The Natural Rate of Interest; 3. Econometric Estimations; \\ 4. The Relevant Literature; 5. Conclusion. \\ Keywords: Natural Rate of Interest; Monetary Policy; Inflation Targeting Regime; Dynamic \\ Taylor Rule. \\ JEL Code: E1; E4; E5.
}

The aim of the present study is to estimate the level of the natural rate of interest in Brazil. First, statistical filters are used for the ex ante and ex post real interest series. Then, an estimation of a dynamic Taylor rule is performed. These two estimates are eventually compared with the natural rate of interest obtained from a simplified macroeconomic state-space model following Laubach and Williams (2003). The results indicate that monetary policy decisions caused the level of the real interest rate to fluctuate around the natural rate of interest, showing that the Brazilian monetary authority can not be characterized as conservative over the analyzed period. O objetivo desse estudo é estimar o nível da taxa natural de juros para o Brasil. Inicialmente filtros estatísticos são usados nas séries de taxas de juros reais ex-post e ex-ante. Depois disso, estima-se uma regra de Taylor dinâmica. Os resultados desses dois experimentos são comparados com a taxa natural de juros que é estimada a partir de um modelo macroeconômico simplificado em formato de espaço de estados, tal como em Laubach and Williams (2003). Os resultados mostram que as decisões de política monetária geraram uma taxa de juros real que flutuou ao redor da taxa de juros natural estimada. Portanto, no período analisado, as autoridades monetárias brasileiras não podem ser caracterizadas, em média, como conservadoras.

\section{INTRODUCTION}

Since the introduction of the inflation targeting in mid 1999, there has been an intense debate concerning the "appropriate" level of the real interest rate in Brazil. The aim of the present study is

\footnotetext{
* The paper has also benefited from discussions with participants of seminars at UnB, UFRGS, ANPEC (2006), Latin American Meeting of the Econometric Society (2008) and the European Meeting of the Econometric Society (2007). The authors would like to thank Pamela Espinosa (FAPERGS), Paulo Fernando Nericke Motula (CNPq) e Diego Baldusco (CNPq) for research assistantship.

$\dagger$ Chief Economist, Banco Cooperativo SICREDI S/A. E-mail: paulo_barcellos@sicredi.com.br

$\ddagger$ Professor of Economics, Universidade Federal do Rio Grande do Sul (UFRGS), and CNPq associate researcher. E-mail: msp@ ufrgs.br
} 
contribute to this debate by estimating the natural rate of interest in Brazil after the implementation of the inflation targeting regime. The comparison between the actual real interest rate and the natural rate of interest will allow us to characterize the monetary policy stance over the analyzed period.

The accurate estimation of the natural rate of interest allows comparing how the Brazilian Central Bank has conducted monetary policy in the last few years with what would be regarded as a theoretically policy-neutral management. That is, a management in which the aim to steer inflation towards the target is consistent with the appropriate growth of activity.

In addition to this introduction, this paper has four other sections. The first section provides a theoretical overview of the definition of the natural rate of interest on which the estimates to be made should be based on. The second section estimates the real long-term interest rate using statistical filters, the real interest rate implicit in monetary policy decisions based on a dynamic reaction function of the Brazilian Central Bank, and the natural rate of interest, based on a simplified macroeconomic state-space model. The subsequent section presents a short survey of the relevant literature on the subject. The last one contains some conclusions and remarks.

\section{THE NATURAL RATE OF INTEREST}

The definition of the natural rate of interest dates back to Wicksell (1936). At that time, monetary theory was strongly influenced by Alfred Marshall and by the Quantitative Theory of Money (QTM). Actually, the work written by Wicksell was based on the QTM and on the aim of providing a more strict theoretical basis for the relationship between the growth of monetary aggregates and inflation. According to Amato (2005), Wicksell developed the definitions of natural rate of interest and interest rate gap as a way to provide a more consistent theory on the determinants of inflation.

"In general, we say, it (the natural rate) depends on the efficiency of production, on the available amount of fixed and liquid capital, on the supply of labor and land, in short on all thousand and one things which determine the current economic position of a community; and it constantly fluctuates" (Wicksell, 1936, p. 106). Throughout his work, we find other definitions of the natural rate of interest, such as (i) interest rate that is consistent with the aggregate price stability; (ii) marginal product of capital; and, (iii) interest rate that equates savings with investment.

Although Wicksell did not establish a common correlation between these definitions, three properties attributed by him to the natural rate of interest should be highlighted: (i) the natural rate of interest is consistent with the idea of equilibrium; (ii) the natural rate is a long-term characteristic; and, (iii) in general, the natural rate of interest cannot be related to a given fixed value, but it can fluctuate due to technological changes that affect capital productivity. These assumptions influenced many studies in the 20th century. Friedman (1968) and Phelps (1968), for instance, used such properties to define the natural rate of unemployment.

According to Wicksell, price stability depends on the interest rate adopted by the central bank visà-vis the natural rate of interest. For Woodford, “(...) inflation occurred whenever the central banks lowered interest rates without any decline in the natural rate having occurred to justify it or whenever the natural rate of interest increased (...) without any adjustment of the interest rates controlled by central banks in response (...)" (Woodford, 2003, p. 49).

The influence of Wicksell's work can be seen in the current New Keynesian equilibrium models. Woodford (2003) refers to these models as "Neo-Wicksellian" framework (hereinafter referred to as NW), clearly acknowledging Wicksell's work. In this theory, the natural rate is obtained from the equilibrium of markets with flexible prices and rational expectations. According to the NW framework, the natural rate of interest has three properties: (i) it is a rate that is defined on a period-by-period basis; (ii) it is obtained in real terms; and, (iii) it is subject to fluctuations in the short and in the long run.

Therefore, even in case of a long-run equilibrium, the natural rate can shift over time due to structural changes in the economy, i.e., in NW models, the natural rate cannot be defined as a constant 
long-term interest rate. According to Amato, “(...) it is a short-term rate, defined period by period, and with a long-run central tendency that can also (slowly) shift over time (...)" (Amato, 2005, p. 3).

A remarkable difference between the natural rate in the New Keynesian approach and the previous models is the equilibrium of the former, which is consistent with a short-term price stability system. Wicksell, Friedman, and other authors who preceded such approach regarded the natural rate as the interest rate towards which the economy would tend in the long run. Thus, the New Keynesian natural rate is a more complete description of the economy in a monetary policy arrangement that has price stability at shorter horizons as one of its major goals, such as the inflation targeting regime. In other words, it is not a level of interests towards which the economy will unfalteringly steer in the long run, but rather a time-varying interest rate that relies on dynamic economic factors and is compatible with an equilibrium.

It is possible to accurately derive a formula for the natural rate in several general equilibrium models. In this regard, one of the contributions of the New Keynesian paradigm is the possibility to obtain an explicit expression for the natural rate by associating it with usual (but sometimes unobservable) economic variables.

According to Woodford (2003) framework, the natural rate of interest derives from an equilibrium between the aggregate demand and a supply curve (Phillips curve), considering a Taylor rule. On the aggregate demand side:

$$
y_{t}=g_{t}+E_{t}\left(y_{t+1}-g_{t+1}\right)-\sigma\left(i_{t}-E_{t} \pi_{t+1}\right)
$$

where $y_{t}$ stands for the aggregate demand at time $t ; g_{t}$ is an exogenous composition that captures changes between income and its marginal utility, derived from shifts in consumers' preferences and from shifts in government spending patterns; $E_{t}$ expectation at time $t ; \sigma$ captures the intertemporal elasticity of aggregate consumption; ${ }^{1} i_{t}$ benchmark interest rate; $E_{t} \pi_{t+1}$ stands for the expected inflation of period $t+1$ at $t$.

On the supply side, one departs from a New Keynesian Phillips curve, as follows:

$$
\pi_{t}=k\left(y_{t}-y_{t}^{*}\right)+\beta\left(E_{t} \pi_{t+1}\right)
$$

where $\pi_{t}$ is the annual inflation rate; $k$ parameter that depends on the frequency of price adjustments in the relationship between marginal cost and level of activity; $\beta$ parameter that measures the sensitivity of inflation to changes in the expectations of economic agents.

One should also consider that the benchmark interest rate is consistent with a Taylor rule, as shown below:

$$
i_{t}=i_{t}^{*}+\phi\left(\pi_{t}-\pi^{*}\right)+\gamma\left(y_{t}-y_{t}^{*}\right)
$$

where $i_{t}^{*}$ measures the intercept, or the real rate compatible with the achievement of targets and with the balanced growth of activity; $\left(y_{t}-Y_{t}^{*}\right)$ output gap $\left(h_{t}\right)$.

Therefore, one obtains a complete system of equations for determination of three endogenous processes $\left(i_{t}, \pi_{t}, y_{t}\right)$, given the behavior of exogenous disturbances $\left(g_{t}, y_{t}^{*}, i_{t}^{*}\right)$.

By rewriting (1) to (3) in terms of output gap $\left(h_{t}\right)$ :

$$
\begin{aligned}
h_{t} & =E_{t} h_{t+1}-\sigma\left(i_{t}-E_{t} \pi_{t+1}-r_{t}^{*}\right) \\
\pi_{t} & =k h_{t}+\beta\left(E_{t} \pi_{t+1}\right) \\
i_{t} & =i_{t}^{*}+\phi\left(\pi_{t}-\pi^{*}\right)+\gamma h_{t}
\end{aligned}
$$

\footnotetext{
${ }^{1}$ The intertemporal elasticity of aggregate demand can be obtained by equation: $\sigma=\frac{C}{y}\left(\frac{u c}{C u c c}\right)$, where the first term corresponds to the total consumption of the aggregate demand, and the second one is the intertemporal elasticity of private consumption.
} 
where $r_{t}^{*}$ is the natural rate of interest.

When the output gap is zero and when the inflation target is identical with the current inflation rate, from equation (6) we have:

$$
i_{t}=i_{t}^{*}
$$

and from (5),

$$
E_{t} \pi_{t+1}=\frac{\pi_{t}}{\beta} \equiv \frac{\pi_{t}^{*}}{\beta}
$$

Isolating $r_{t}^{*}$ in (4) and making the substitutions:

$$
r_{t}^{*}=i_{t}^{*}-\frac{\pi_{t}^{*}}{\beta}-\frac{E_{t} h_{t-1}}{\sigma}
$$

Thus, when the inflation target and a zero output gap are obtained, the natural rate of interest will depend on the constant estimated by the Taylor rule ${ }^{2}\left(i_{t}^{*}\right)$, on the inflation target $\left(\pi_{t}^{*}\right)$, on the sensitivity of the current inflation rate to future expectations regarding the behavior of prices $(\beta)$, on the expectations regarding the behavior of the output gap $\left(E_{t} h_{t+1}\right)$ and on the intertemporal elasticity of aggregate consumption $(\sigma)$.

Note that the natural rate is not independent of the different forms of nominal rigidity faced by the economy in the recent past. For example, a monetary policy that introduced inflation inertia may add remarkable persistence to the natural rate dynamics. That is to say, the occurrence of economic shocks may be more persistent and imply higher natural rates when the past shock is dampened instead of eliminated by the monetary policy. However, under some circumstances, the immediate elimination of a shock may certainly generate excessively high costs in the long run, explaining a certain degree of accommodation in these cases. This postulate is quite relevant to the Brazilian case, where a representative set of events that are not directly related to monetary policy, such as foreign crises and political uncertainty, led to inflationary pressures that resulted in high levels of real interest rates after the implementation of the inflation targeting regime.

\section{ECONOMETRIC ESTIMATIONS}

As the natural rate of interest is a variable that cannot be directly observed, it can be estimated by different methods. In the present study, we opted to use a simplified macroeconomic model for the Brazilian economy, where the equilibrium between the aggregate supply and aggregate demand allows extracting the natural rate of interest. Before that, however, other two variables, which will play an important role in the qualitative analysis of results, are estimated: the real long-term interest rate and the neutral rate implicit in the decisions taken by the Brazilian Central Bank. These estimations are respectively made using statistical filters and a dynamic Taylor rule.

\subsection{Statistical filters}

A relatively straightforward way to obtain the real long-term interest rate is by using the statistical filters employed in the real interest rate series. This estimation method is usually found in the literature, as in the work published by Muinhos and Nakane (2006) for the Brazilian case. In the present study, we used two types of filters that are widely referred in the literature, the Hodrick-Prescott filter and the

\footnotetext{
${ }^{2}$ The estimates of a reaction function are not usually made for supposing that the output gap is zero and that the inflation target has been achieved. Thus, the benchmark interest rate should be used instead of the constant in the Taylor rule to obtain the natural rate from this equation.
} 
Band-Pass ${ }^{3}$ filter in ex ante and ex post real interest rate series. The ex post real interest rate series was obtained by deflating the benchmark Selic rate according to the Consumer Price Index (CPI) accumulated throughout twelve months, whereas the ex ante real interest rate series was obtained by deflating the expected benchmark (Selic) rate twelve months ahead according to the smoothed CPI inflation expectation series for the subsequent twelve months, calculated in the market survey conducted by the Brazilian Central Bank. ${ }^{4}$

Figure 1 shows the results obtained with the filters. The BP filter, by methodological definition, tends to yield more volatile results compared to those obtained from the HP filter. It is interesting to note the similarity of results in the comparison between the measures of central tendency (mean and median) of the ex post real long-term interest rates and the ex ante real interest rates, which may be attributed to the fact that the inflation and the decisions about the effectively implemented monetary policy were close to the expectations of the economic agents. As expected, the real interest rate obtained by the filters showed fluctuation, reflecting different short-term moments, although its levels remained high for international standards in a similar timeframe. According to Muinhos and Nakane (2006), for instance, the average real interest rate for a large sample of emergent economies corresponded to $4.7 \%$ between 2000 and 2004, which was well below the values obtained for the Brazilian case (Figure 1).

\subsection{Dynamic Taylor rule}

The reaction function proposed by Taylor (1993) establishes that monetary policy decisions regarding the behavior of the benchmark interest rate may be well represented by a linear relationship, whose major component is the natural interest rate, which was originally set at $2 \%$ for the U.S. economy. Thereafter, a comprehensive literature has been developed to estimate reaction functions for central banks around the globe, considering, in general, the equilibrium rate as the constant to be determined by the regression. Clarida et al. (1999) mentioned that in a situation in which deviations of inflation from its target and deviations of economic activity from its potential level equal zero, the intercept could be understood as the equilibrium real interest rate. Therefore, based on the principle that central banks seek to achieve their inflation targets by keeping a balanced economic growth, the intercept of the reaction function determines the real interest rate that should be used for this purpose.

Leigh (2005), in his turn, emphasized that as the natural rate of interest is affected by dynamic factors (e.g.: productivity growth), taking for granted that the natural rate is properly represented by the constant in the Taylor rule could be extremely restrictive. In an attempt to provide an alternative solution to this problem, Leigh (2005) estimated a dynamic reaction function for the U.S. economy, where the natural rate of interest was no longer a constant, but a variable intercept of the function instead. To accomplish that, the author separately estimated the natural rate using the method proposed by Laubach and Williams (2003), later obtaining a reaction function where the natural rate was a time-varying parameter.

In the present study, we will do the inverse of this process, i.e., the equilibrium interest rate will be extracted from the reaction function using a dynamic model for the Taylor rule intercept. This procedure allows extracting the real interest rate with which the Brazilian Central Bank worked implicitly throughout the analyzed period, in an attempt to achieve its inflation targets and to help smoothing the short-term business cycles. So, as the reaction function of the Brazilian Central Bank is the starting point, the real rate derived from this function can be understood as the equilibrium interest rate implicit in monetary policy decisions throughout the analyzed period that tend to eliminate the output gap and the deviations of inflation expectations from inflation targets. This way, the comparison of this

\footnotetext{
${ }^{3}$ The method proposed by Christiano and Fizgerald (2003) was used for the Band-Pass filter. For a formal introduction to and a comparative analysis of the Hodrick and Prescott (HP) and Band-Pass (BP) filters, see Toledo (2004).

${ }^{4}$ This survey is fully available at http://www.bcb.gov.br/?FOCUSERIES.
} 
Figure 1: Natural rates of interest in Brazil - Statistical filters (HP and BP)

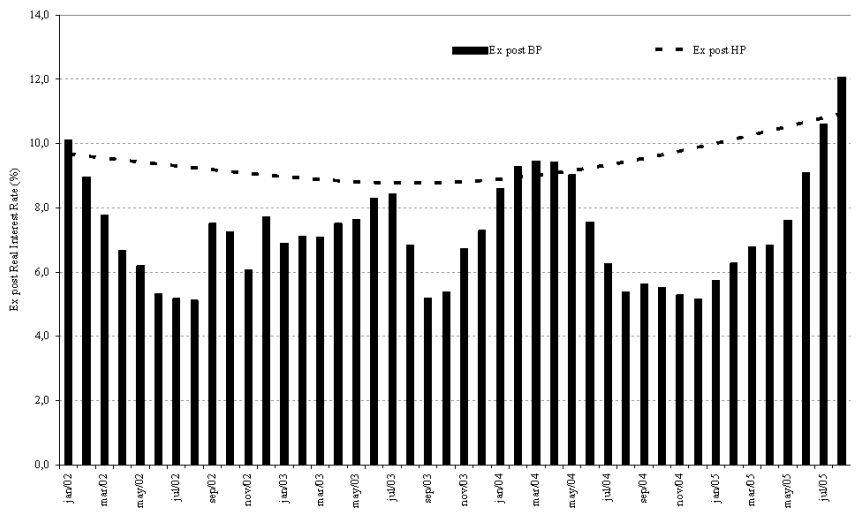

(a) Filters in the ex post Real Interest Rate

\begin{tabular}{llc}
\hline ex post & BP & HP \\
\hline Mean & 7.28 & 9.40 \\
Median & 7.10 & 9.24 \\
Standard deviation & 1.61 & 0.59 \\
\hline Period: & \multicolumn{2}{l}{ Jan/2002 - Aug/2005 } \\
\hline
\end{tabular}

(b) ex post summary

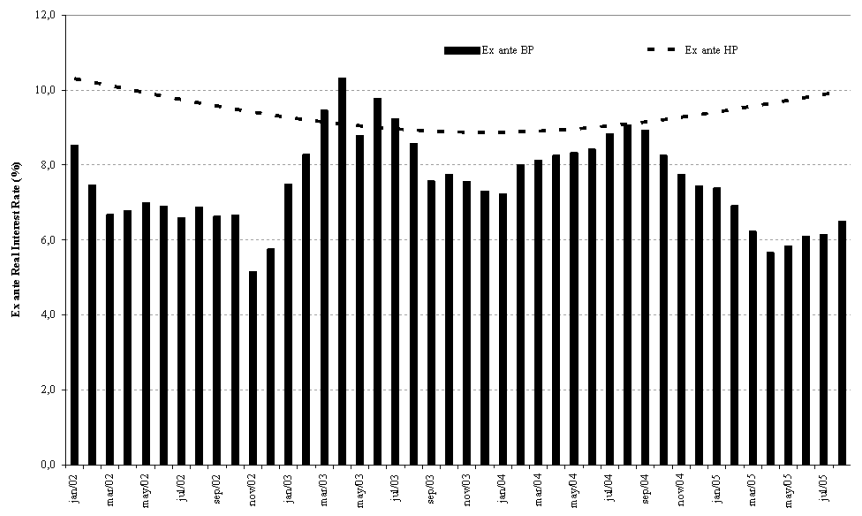

(c) Filters in the ex ante Real Interest Rate

\begin{tabular}{llc}
\hline ex ante & BP & HP \\
\hline Mean & 7.56 & 9.37 \\
Median & 7.49 & 9.27 \\
Standard deviation & 1.18 & 0.42 \\
\hline Period: & \multicolumn{2}{l}{ Jan/2002 - Aug/2005 } \\
\hline
\end{tabular}

(d) ex ante summary 
rate with the natural rate of interest allows for a qualitative analysis of how conservative the monetary policy decisions taken by the Brazilian Central Bank are.

The estimation of the real interest rate consistent with the reaction function was made using the Kalman filter, with the following structure:

$$
\begin{aligned}
i_{t} & =r_{e t}^{*}+\beta_{1} i_{t-1}+\beta_{2} D_{j, t}+\beta_{3} h_{t-2}+\varepsilon_{t, 1} \\
r_{e t}^{*} & =r_{e, t-1}^{*}+\varepsilon_{t, 2}
\end{aligned}
$$

where $r_{e t}^{*}$ is the real interest rate implicit in the decisions made by the monetary authority; $i_{t}$ nominal benchmark Selic rate (monthly); $i_{t-1}$ nominal benchmark Selic rate lagged one period; $D_{j, t}$ weighted deviation of expected inflation from the inflation target; ${ }^{5} h_{t-2}$ output gap ${ }^{6}$ lagged two periods.

This set of equations can be represented in the state-space form as:

$$
\begin{gathered}
{\left[i_{t}\right]=\left[\beta_{1} \beta_{2} \beta_{3} r_{e t}^{*}\right]\left[\begin{array}{c}
i_{t-1} \\
h_{t-2} \\
D_{j, t} \\
1
\end{array}\right]+\left[\varepsilon_{t, 1}\right] \quad \text { (Measurement Equation) }} \\
{\left[\begin{array}{c}
\beta_{1, t} \\
\beta_{2, t} \\
\beta_{3 t} \\
r_{e t}^{*}
\end{array}\right]=\left[\begin{array}{llll}
1 & 0 & 0 & 0 \\
0 & 1 & 0 & 0 \\
0 & 0 & 1 & 0 \\
0 & 0 & 0 & 1
\end{array}\right]\left[\begin{array}{c}
\beta_{1, t-1} \\
\beta_{2, t-1} \\
\beta_{3, t-1} \\
r_{e t-1}^{*}
\end{array}\right]\left[\begin{array}{c}
0 \\
0 \\
0 \\
\varepsilon_{t, 2}
\end{array}\right] \quad \text { (State or Transition Equation) }}
\end{gathered}
$$

This framework for the Brazilian reaction function is in agreement with studies that estimated the Taylor rule for Brazil, such as the one conducted by Minella et al. (2002), whose major difference lies in the intercept dynamics, which in the present case varies over time, following a random walk in the state equation. Figure 2 shows the results for the estimation of the natural rate of interest derived from the dynamic Taylor rule. The standard deviation of 0.88 indicated that the series is as stable in this procedure as in the estimates made using the HP filter, whereas the mean of $7.38 \%$ was similar to that obtained with the BP filter in the ex post and ex ante real interest rate series. These results show that the Brazilian monetary authority worked explicitly or implicitly with a real interest rate close to the results yielded by the filters.

The period in which the estimated real rate was higher (Dec/02 - May/03, with mean of 9.02\%) coincides with the period in which the Brazilian central bank made a deliberate effort, as outlined in the Monetary Policy Committee minutes, to control imminent inflationary pressures, caused by a strong exchange rate depreciation in the second half of 2002. In this regard, the behavior of the real interest rate extracted from the reaction function is coherent with the short-term aspects of the monetary policy decisions that prevailed at that time.

\subsection{The simplified macroeconomic model}

Since the natural rate of interest is not a directly observed variable, some hypotheses about its determinants are necessary, so that it is possible to extract it from econometric models. The method

\footnotetext{
${ }^{5}$ This variable was constructed following the suggestion made in Minella et al. (2002), where: $D_{j, t}=\left(\frac{12-j}{12}\right)\left(E_{j} \pi_{t}-\pi_{t}^{*}\right)+$ $\left(\frac{j}{12}\right)\left(E_{j} \pi_{t+1}-\pi_{t+1}^{*}\right)$, where $E_{j} \pi_{t}=$ expectation in month $j=1,2, \ldots, 12$ for inflation in year $t$; $\pi_{t}^{*}=$ midpoint target range for year $t ; E_{j} \pi_{t+1}=$ expectation in month $j$ for inflation of year $t+1 ; \pi_{t+1}^{*}=$ midpoint target range for year $t+1$.

${ }^{6}$ IBGE's monthly industrial output series with seasonal adjustment was used as a proxy for the output, and the series obtained from the Hodrick-Prescott filter was used as potential output.
} 
Figure 2: Natural rate of interest in Brazil - Dynamic Taylor rule

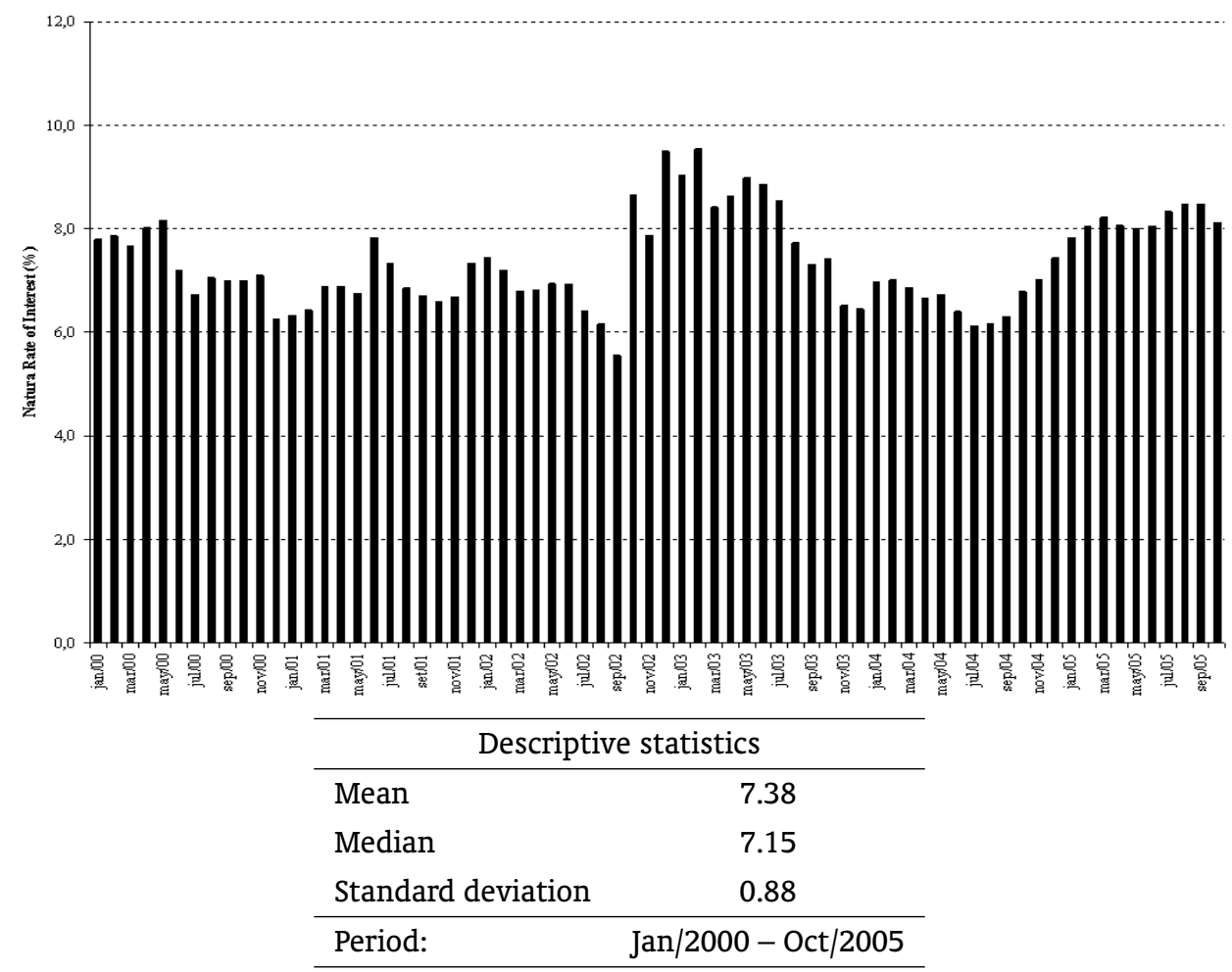

proposed by Laubach and Williams (2003) for the U.S. economy, in which a simplified macroeconomic structure of the economy provides a path for the natural rate, will be used as a reference in the present study. The model is based on two macroeconomic equations, an aggregate supply curve and an aggregate demand curve, where market equilibrium allows extracting the behavior of the natural rate of interest from the economy. There are two basic assumptions about the method proposed by the authors: (i) the output gap converges towards zero whenever the interest rate gap - difference between real interests and the natural rate - is zero; and, (ii) fluctuations in inflation converge towards zero if the output gap is zero. To estimate the model one should use the demand (IS) and supply (Phillips curve) equations in state-space form, as it allows the extraction of the behavior of unobserved variables. Note that the model is not restricted to countries that do not adopt explicit inflation targets, as in the U.S. case, without any restrictions as to its use in a target regime.

The first step is to define an equation for aggregate demand in the shape of an IS curve:

$$
y_{t}=c+y_{t}^{*}+A_{y}(L)\left(h_{t}\right)+A_{R}(L)\left(i_{R t}\right)+\varepsilon_{t, 1}
$$

where $c$ constant; $y_{t}^{*}$ potential output; $h_{t}$ output gap; $i_{R t}$ interest rate gap (real interest rate $\left(r_{e t}\right)$ minus the natural rate of interest $\left.\left(r_{t}^{*}\right)\right)$; $\varepsilon_{t, 1}$ error term, I.I.D. $\sim N\left(0, \sigma^{2}\right)$.

The supply side is represented by a New Keynesian Phillips curve:

$$
\pi=B_{y}(L)\left(h_{t}\right)+B_{\pi}(L)\left(E_{t}\left(\pi_{t+1}\right)\right)+B_{\pi}(L)\left(\pi_{t-1}\right)+\varepsilon_{t, 2}
$$


where $\pi_{t}$ inflation accumulated throughout 12 months (CPI); $E_{t}$ expectation vector at $t ; \varepsilon_{t, 2}$ error term, I.I.D. $\sim N\left(0, \sigma^{2}\right)$.

The combination of these equations is consistent with the assumption that price stability is obtained through the equality between interests and output to their respective natural rates. Unobservable variables are defined in state equations.

Natural rate $r^{*}$ follows the equation:

$$
r^{*}=c g_{t}+z_{t}
$$

where $c$ constant; $g_{t}$ growth tendency of the output's natural rate, or growth of economic productivity; $z_{t}$ stochastic term that represents other determinants of $r^{*}$.

Variable $z_{t}$ is believed to follow a random walk or an $\operatorname{AR}(\mathrm{d})$ process.

$$
z_{t}=D_{z}(L) z_{t-1}+\varepsilon_{t, 3}
$$

The potential output depends on unobservable components that follow a random walk, and the transition equations are represented by:

$$
\begin{aligned}
y_{t}^{*} & =y_{t-1}^{*}+g_{t-1}+\varepsilon_{t, 4} \\
g_{t} & =g_{t-1}+\varepsilon_{t, 5}
\end{aligned}
$$

This set of equations can also be defined in state-space form. By writing equations (12) and (13) in terms of output gap $\left(h_{t}\right)$, and of interest rate gap $\left(i_{R t}\right)$, this set of equations can be represented in the state-space form.

$$
\begin{gathered}
{\left[\begin{array}{l}
h_{t} \\
\pi_{t}
\end{array}\right]=\left[\begin{array}{ccc}
c & A_{1} & A_{2} \\
B_{1} & B_{2} & B_{3}
\end{array}\right]\left[\begin{array}{cc}
1 & h_{t-1} \\
h_{t-1} & E\left(\pi_{t+1}\right) \\
i_{R, t-1} & \pi_{t-1}
\end{array}\right]+\left[\begin{array}{c}
\varepsilon_{t, 1} \\
\varepsilon_{t, 2}
\end{array}\right] \quad \text { (Measurement Equation) }} \\
{\left[\begin{array}{c}
z_{1, t} \\
z_{2, t} \\
y_{t}^{*} \\
g_{t}
\end{array}\right]\left[\begin{array}{cccc}
D_{1} & D_{2} & 0 & 0 \\
0 & 1 & 0 & 0 \\
0 & 0 & 1 & 1 \\
0 & 0 & 0 & 1
\end{array}\right]\left[\begin{array}{c}
z_{1, t-1} \\
z_{2, t-1} \\
y_{t-1}^{*} \\
g_{t-1}
\end{array}\right]+\left[\begin{array}{c}
\varepsilon_{t, 3} \\
0 \\
\varepsilon_{t, 4} \\
\varepsilon_{t, 5}
\end{array}\right] \quad \text { (State Transition Equation) }}
\end{gathered}
$$

The solution to this system allows determining the evolutionary pattern of the variables on which the behavior of the natural rate is conditioned. However, Stock and Watson (1998) draw attention to the fact that estimations of this type of model tend to yield biased results due to the occurrence of "pile-up problem". To solve this bias, it is recommended that a sequential estimation process, which provides consistent estimations, be carried out. ${ }^{7}$

First, the potential output is estimated, disregarding the existence of an interest rate gap and restricting the variance of the state equation to zero. That is:

$$
\begin{aligned}
y_{t} & =Y_{t}^{*}+\varepsilon_{1, t} \\
y_{t}^{*} & =Y_{t-1}^{*}+g_{t-1}+\varepsilon_{2, t} \\
g_{t} & =g_{t-1}
\end{aligned}
$$

${ }^{7}$ See also Laubach and Williams (2003). 
After $y^{*}$ is obtained, the system is estimated again, by making $y^{*}$ an exogenous variable (estimated in the previous step) and by adding the error to the last state equation:

$$
\begin{aligned}
y_{t} & =y_{t}^{*}+\varepsilon_{1, t} \\
y_{t}^{*} & =y_{t-1}^{*}+g_{t-1}+\varepsilon_{2, t} \\
g_{t} & =g_{t-1}+\varepsilon_{3, t}
\end{aligned}
$$

After that, one obtains parameter $\lambda_{g}$ which will be multiplied by the error of the state equation (28).

$$
\lambda_{g}=\frac{\sigma_{3, t}}{\sigma_{2, t}}
$$

By assuming that $z_{t}$ follows an $\operatorname{AR}(1)$, the full system is estimated as follows: Measurement Equations:

$$
\begin{aligned}
& y_{t}=y_{t}^{*}+\alpha_{1}\left(r e_{t-1}-r^{*}\right)+\alpha_{2}\left(y_{t-1}-y_{t-1}^{*}\right)+\varepsilon_{4, t} \\
& \pi_{t}=\alpha_{3}\left(y_{t-1}-y_{t-1}^{*}\right)+\alpha_{4} E_{t}\left(\pi_{t+1}\right)+\alpha_{5}\left(\pi_{t-1}\right)+\varepsilon_{5, t}
\end{aligned}
$$

State or Transition Equations:

$$
\begin{aligned}
r_{t}^{*} & =\alpha_{6} g_{t-1}+z_{t-1} \\
y_{t}^{*} & =y_{t-1}^{*}+g_{t-1}+\lambda_{g} \varepsilon_{2, t} \\
g_{t} & =g_{t-1}+\varepsilon_{3, t} \\
z_{t} & =\alpha_{7}+\alpha_{8} z_{t-1}+\varepsilon_{6, t}
\end{aligned}
$$

The implementation of this process allowed obtaining a path for the natural rate of interest in Brazil during the inflation targeting regime. As shown in Figure 3, the mean and median for the natural rate were $9.41 \%$ and $9.52 \%$, respectively, and the standard deviation was close to that found in real interest rate estimates (1.56). The rate was very close to the one obtained from other estimations made in this study, showing convergence between the most commonly used interests and the natural rate. Special attention should be paid to the fact that the rate showed some changes in its level during the analyzed period, being as low as $5 \%$ in late 2003 and as high as $12.5 \%$ at the beginning of the second half of 2005. This fluctuation may reflect the peculiarities of the Brazilian economy in that period, when strong changes in macroeconomic variables were observed as a result of the shocks that had been inflicted since 1999. The pre-election crisis in 2002, for instance, required that the Brazilian monetary authority take a very strong stance in the subsequent year, causing explanatory variables of the natural rate, such as output gap, inflation, and inflation expectations, to have a volatile behavior in that period.

As far as the conduct of monetary policy is concerned, the direct comparison between the average ex ante and ex post real interest rates and the natural rate yields remarkably similar results, something around 9.4\%. Despite this similarity, it is necessary that a dynamic comparison between estimations be made in order to make more in-depth conclusions, because the measures of central tendency may omit changes in the behavior of the series.

Figure 4 shows the behavior of two interest rate gap estimates. In the first one, the gap results from the difference between ex ante real interests and the natural rate, whereas in the second one, there is a difference between the real interest rate implicit in the Taylor rule and the natural rate. Supposedly, as the monetary authority tries to assume a policy-neutral stance on the determination of the benchmark interest rate, the comparison of the natural rate with these two estimates should yield results that are 
Figure 3: Natural rate of interest in Brazil - State-space model

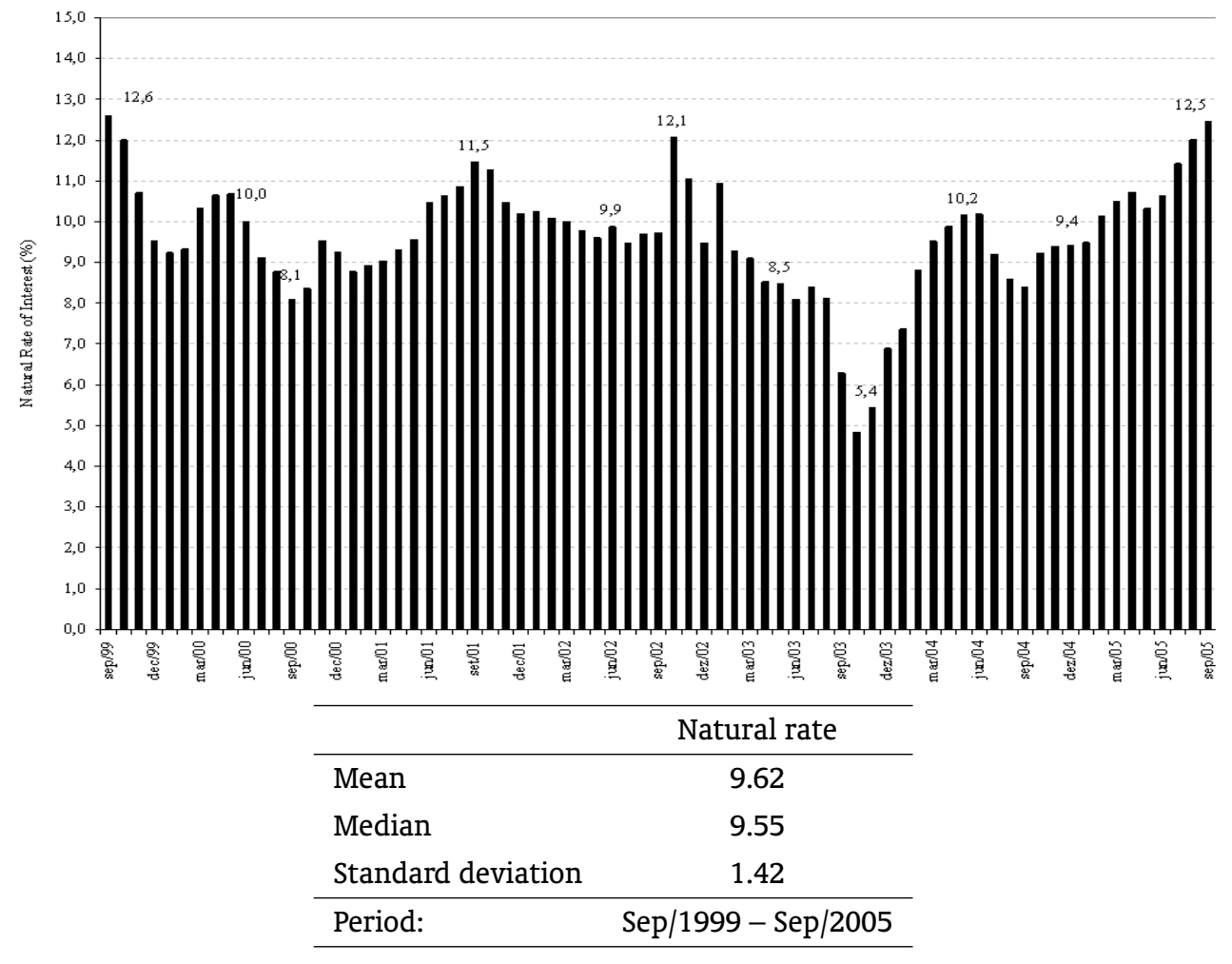

very close to zero, since persistently positive output gaps indicate conservative monetary policy, while persistently negative ones indicate an expansive policy.

The comparison of both gap estimates shows that monetary policy decisions in the targeting regime were actually forward-looking, since the confrontation between the movements of the real interest rate implicit in the reaction function with ex ante real interest rates revealed similar results most of the time, although the result for the evolution of the gap obtained by the Taylor rule was smaller than that of the gap for the ex ante real interest rates. Given the behavior of the ex ante gap, the results indicate a tendency towards a neutral monetary policy, as the average gap was close to zero ( -0.01$)$, but its evolution revealed non-negligible differences in regard to what would be understood as a neutral behavior. In 2003, for instance, there was a tendency towards a positive gap, which is compatible with the acknowledged effort of the Central Bank to fight inflation inertia caused by economic shocks in 2002. On the other hand, the Taylor rule gap had a more expansive average behavior, with a mean of -1.96 , showing a nonconservative bias in monetary policy most of the time.

Even though there may be some subjectivity when determining which gap is actually the most appropriate to establish the Central Bank's degree of accuracy over time, both estimates refute the idea of an overly systemic conservative approach by the Monetary Policy Committee during the inflation targeting regime. As a matter of fact, the gaps indicate that the decisions about the determination of the benchmark interest rate kept the real interest rate either close to the estimated natural rate or below this level most of the time, which is consistent with the idea of a relatively neutral Central Bank in terms of monetary policy decisions. 
Figure 4: Interest rate gap (Nov/2001 - Sep/2005)

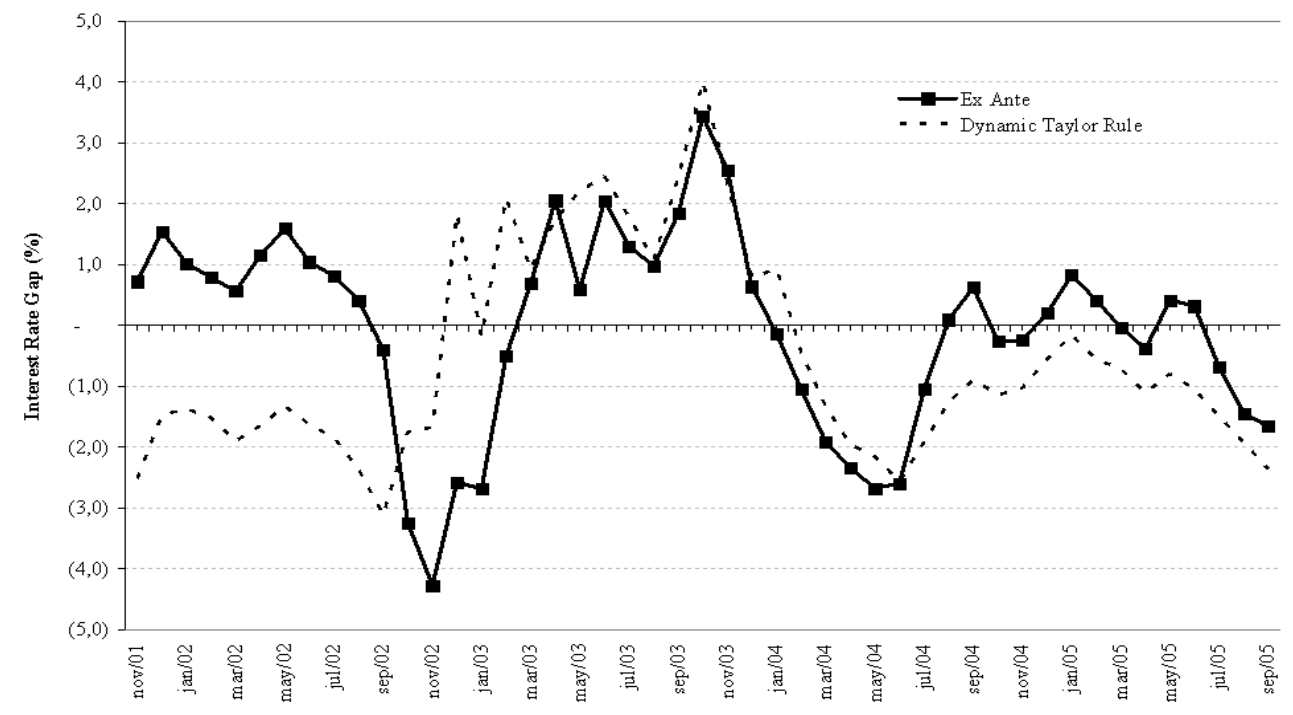

\section{THE RELEVANT LITERATURE}

The Brazilian literature, specially Miranda and Muinhos (2003), Arida et al. (2005), Gonçalves et al. (2005) and Muinhos and Nakane (2006) are concerned with determining the major reasons for the persistently high levels of real interest rates in Brazil comparatively to those of both industrialized and developing countries. The present study, on the other hand, has focused on the estimation of the natural rate of interest using a simplified macroeconomic model and then on analyzing the results in terms of the conduct of monetary policy. Our analysis, therefore, compares the natural rate of interest with both the actual real interest rate and the estimated real interest rate implicit in a dynamic reaction function of the Brazilian Central Bank.

Note that there exists a strong relationship between the definitions of natural rate of interest and real interest rate. The natural rate of interest, or equilibrium interest rate, can be defined as a real interest rate that is consistent with a zero output gap and with a constant inflation rate, or compatible with the implemented inflation target, as initially suggested by Wicksell (1936). Thus, whenever the real short-term interest rate is above the natural rate of interest, we have a restrictive or disinflationary monetary policy; when the real interest rate is below the natural rate of interest instead, we have an expansive monetary policy. Since the real interest rate is expected to return to its natural level in the long run, the close relationship between the definitions becomes apparent.

Amato (2005) makes an interesting argument about the role of the natural rate of interest in the conduct of monetary policy in a context in which the inflation targeting regime is adopted by several central banks. For the author, the importance of the natural rate of interest is closely related to monetary policy goals. In an inflation targeting regime with an autonomous monetary authority, where price stability and reduction of the output gap are the main objectives, the natural rate of interest is basically one of the major indicators of an appropriate monetary policy. However, the author points out the difficulties in making an accurate empirical estimation of this rate, as such information is not 
directly observed - just as other important economic definitions, such as the natural exchange rate, output gap, and non-accelerating inflation rate of unemployment, or NAIRU. ${ }^{8}$

Laubach and Williams (2003) pointed out that the estimation of the equilibrium interest rate has not been sufficiently covered by the literature, even in industrialized countries, despite its importance to the conduct of an appropriate monetary policy. The study carried out by these authors has been frequently cited in the literature due to the fact that they used an IS-AS model with dynamic coefficients, in statespace models, to estimate the natural rate of interest for the U.S. economy. Leigh (2005) used the model developed by Laubach and Williams (2003) to estimate a Taylor rule that includes the estimation of the natural rate of interest for the U.S. in the linear coefficient of the equation. The estimations in both studies yielded satisfactory results in terms of methodology regarding the determination of the natural rate of interest for the U.S. economy, and will be used as a benchmark for the estimations performed herein.

In Brazil, Miranda and Muinhos (2003) sought to determine the equilibrium interest rate for a sample of different countries, placing special emphasis on Brazil, through different methods. The results obtained by the authors are extremely sensitive to the methods used, in such a way that it was not necessary to determine the equilibrium interest rate for the Brazilian economy in the analyzed period. As the authors themselves put it, this uncertainty is related to the short time elapsed between the shift in the Brazilian exchange rate regime (1999) and their study. ${ }^{9}$ Nevertheless, despite such limitations, their investigation, which is one of the groundbreaking studies on inflation targeting in Brazil, shows that the equilibrium interest rate is quite high compared to that of industrialized and developing countries.

Arida et al. (2005) investigated the role of jurisdictional uncertainties in the determination of high levels of real interest rates for Brazil, and their work has become a reference source in the current literature on this topic. Firstly, the authors assessed the three major and most common explanations for the high levels of real interest rates in Brazil after price stabilization in 1994: ${ }^{10}$ (i) conservative monetary policy; (ii) loose fiscal policy; and, (iii) short-term external crises.

The exchange rate band system in effect until early 1999 kept the real interest rate at high levels in Brazil, which was used to attract foreign capital in order to help keep the balance of payments in equilibrium. After the shift in the exchange rate system and after the implementation of the inflation targeting regime, monetary policy turned out to be conservative for being under some fiscal dominance, ${ }^{11}$ or being subjected to a "bad equilibrium". Thus, the extremely high levels of real rate interests increased the default risk of public debt. Ceteris paribus, one could obtain the same inflation rate by reducing the benchmark interest rate, diminishing debt costs, and bringing the Brazilian economy to a "good equilibrium".

The second cause pointed out by the study indicates that the fragility of public accounts brings rigidity to the level of real interest rates even with primary surpluses in the public sector since 1999, as the public sector's consolidated net debt exceeds 50\% of the GDP. In other words, the large financing necessity of the public sector in a country with low savings rate increases the interest rate required by creditors to finance the Brazilian government. In addition to the size of the debt, its composition would also contribute to the high level of real interest rates. According to consolidated data of August 2005, 56.85\% of the domestic federal public bond debt was allocated in Financial Treasury Bills (LFT's) - applications pegged to the benchmark Selic interest rate. Holders of fixed-rate public debt bonds have larger monetary losses whenever the benchmark interest rate increases, enhancing the restrictive impact of a tight monetary policy by way of the "wealth effect". But in the case of Brazil, the high

\footnotetext{
${ }^{8}$ Tejada and Portugal (2002), for instance, estimate a NAIRU for the Brazilian economy using variable parameters.

${ }^{9}$ Second quarter of 2002.

${ }^{10} \mathrm{~A}$ descriptive analysis of these causes can be found in Revista Conjuntura Econômica, vol. $59 \mathrm{n}$ 9, September 2005.

${ }^{11}$ For further details about this issue, see Gonçalves and Guimarães (2005) and Blanchard (2005).
} 
indexation to floating-rate bonds minimizes ${ }^{12}$ this effect and, as a result, higher benchmark interest rates are necessary to fight inflation.

The third argument reveals that the short-term shocks that had assailed Brazil since $1999^{13}$ are the reasons for such high levels of real interest rates. In other words, the real interest rate in Brazil in the last few years would be under a short-term bias, since economic tensions probably led the monetary authority to "impose" a more conservative approach after the implementation of the inflation targeting regime. This argument, however, leads to the assumption that as these events lose their importance in the determination of relative prices, a decrease in real interest rates may naturally occur.

For Arida et al. (2005), these observations, although relevant, do not cover the topic exhaustively, as they do not deal objectively with the shortage of a sizeable long-term bond market in Brazil that allows for a longer interest rate curve. The authors suggest that "jurisdictional uncertainties" and the current capital control are the main reasons for the high levels of real interest rates in Brazil. Thus, the joint effect of a bad institutional environment - with debtor-friendly laws - on one hand, and of capital control, on the other hand, produces a situation in which the financial system requires a higher interest rate to finance the State, implying the demand for higher-than-necessary levels of interest rates to control inflation.

Based on these reasons, Gonçalves et al. (2005) empirically analyze the importance of jurisdictional uncertainty and of capital account restrictions to determine the level of real interest rate in a significant sample of countries. The results obtained are not consistent with the arguments presented by Arida et al. (2005), since traditional macroeconomic variables, such as price level and domestic level of indebtedness, are the major explanations to the level of interest rate observed in the analyzed sample. Likewise, Fraga (2005) advocates that, in spite of its academic and operational relevance for monetary policy, jurisdictional uncertainty is more suitable to explain the high cost of credit (spreads) in Brazil than the level of the benchmark interest rate, which is still strongly correlated with macroeconomic variables (e.g.: low savings rate) and with the past record of default.

\section{CONCLUSION}

The definition of natural rate of interest has been dealt with in the literature since the groundbreaking work published by Wicksell in 1936, and has been gaining momentum in the current monetary policy arrangement on a worldwide basis, especially in countries that have implemented the inflation targeting regime. However, as observed by Amato (2005), although this topic is relevant, it has not been given due attention in today's research, maybe because it cannot be directly observed. Therefore, the aim of the present study was to address this topic and specifically analyze the Brazilian case.

Although price stability has been achieved since 1994, the inflation targeting regime went into effect only in 1999, and analysts and researchers have turned their attention to the high level of real interest rates, due to its negative effects on economic growth, on the increase of domestic public debt, on the necessity of a tight fiscal policy, among others.

Despite the fact that the Brazilian literature on this topic is still evolving, it has considerably expanded, and works such as those by Arida et al. (2005), Gonçalves et al. (2005) and Muinhos and Nakane (2006) are good examples of this. Nevertheless, aside from some preliminary signs, no consensus has been reached so far about the whys and wherefores of Brazil's highest levels of real interest rates. To investigate further into this topic, it is necessary to find out the level of natural rates of interest for Brazil,

\footnotetext{
${ }^{12}$ Negotiations in the bond market require that a premium be paid, and therefore changes in the monetary policy that are not predicted by the market on interest rate curves result in financial losses in the marking-to-market of bonds, even in the case of floating-rate bonds.

${ }^{13}$ The most commonly cited events are: the Nasdaq bubble burst, power rationing, the terrorist attack of September 11 , and the Argentine collapse, all in 2001, and the crisis of confidence due to the 2002 elections. For further information, see Barcellos and Portugal (2003).
} 
because only monetary policy decisions that result in the systematic behavior of keeping the real rate above the natural rate can be characterized as conservative or otherwise. Thus, the estimation of the level of natural rates of interest compatible with an inflation targeting regime and with the supply and demand structure of the Brazilian economy is a way to shed some light on the problem.

Besides showing the chronological behavior of the definition of natural rate, the present study estimated the natural rate of interest by using, at first, a simplified macroeconomic model and then comparing its evolution with real interest rates and with the real interest rates implicit in the Central Bank's decisions, based on a dynamic Taylor rule. Results suggest that the level of the Brazilian natural rate of interest is actually high for international standards. Even after admitting that there may be some limitations in reaching definitive conclusions about this topic (e.g.: relatively short series for a definition that is associated with long-run equilibrium), it should be highlighted that the results are compatible with those works that had a similar aim, even when they used different estimation methods, and also that the results are methodologically robust.

The results obtained are not consistent with the arguments that Brazilian monetary policy has been extremely rigid about the determination of the benchmark interest rate in order to achieve the predefined inflation targets. Although the Central Bank showed to be more rigid than indicated by the sometimes policy-neutral stance, the monetary authority kept the ex ante real interest rate and the implicit natural rate of the reaction function close to or below the natural rate most of the time. The results also indicate that in order for Brazil to consistently reduce its real interest rates, there should be some changes in the factors that affect the natural rate, such as the increase in the total factor productivity, changes in the intertemporal elasticity of consumption or in the sensitivity of inflation to the expectations of economic agents, instead of a lenient monetary policy.

\section{BIBLIOGRAPHY}

Amato, J. (2005). The role of natural rate of interest in monetary policy. Technical Report 171, Bank for International Settlements (BIS).

Arida, P., Bacha, E., \& Lara-Resende, A. (2005). Credit, interest and jurisdictional uncertainty: Conjectures on the case of Brazil. In Giavazzi, F., Goldfajn, I., \& Herrera, S., editors, Inflation Targeting, Debt and the Brazilian Experience, 1999 to 2003. MIT Press.

Barcellos, P. \& Portugal, M. (2003). Os primeiros seis meses de política econômica do governo Lula: Exorcizando o fantasma da ruptura. Revista Análise Econômica, 40:273-282.

Blanchard, O. (2005). Fiscal dominance and inflation targeting: Lessons from Brazil. In Giavazzi, F., Goldfajn, I., \& Herrera, S., editors, Inflation Targeting, Debt and the Brazilian Experience, 1999 to 2003. MIT Press.

Christiano, L. \& Fizgerald, T. (2003). The band-pass filter. International Economic Review, 44(2):435-465.

Clarida, R., Gali, J., \& Gertler, M. (1999). The science of monetary policy: A new Keynesian perspective. Technical Report 7147, NBER.

Fraga, A. (2005). Fiscal dominance and inflation targeting: Lessons from Brazil. In Giavazzi, F., Goldfajn, I., \& Herrera, S., editors, Inflation Targeting, Debt and the Brazilian Experience, 1999 to 2003. MIT Press.

Friedman, M. (1968). The role of monetary policy. American Economic Review, 58:1-17.

Gonçalves, C. E. \& Guimarães, B. (2005). Monetary policy and the exchange rate in Brazil.

Gonçalves, F., Holland, M., \& Spacov, A. (2005). Can jurisdictional uncertainty and capital controls explain the high level of real interest rates in Brazil? Evidence from panel data. 
Laubach, T. \& Williams, J. (2003). Measuring the natural rate of interest. The Review of Economics and Statistics, 83:218-231.

Leigh, D. (2005). Estimating the implicit inflation target: An application to U.S. monetary policy. Technical Report 77, IMF.

Minella, A., Goldfajn, I., \& Muinhos, M. (2002). Inflation targeting in Brazil: Lessons and challenges. Technical Report 53, Banco Central do Brasil.

Miranda, P. \& Muinhos, M. (2003). A taxa de juros de equilíbrio: Uma abordagem múltipla. Technical Report 66, Banco Central do Brasil.

Muinhos, M. \& Nakane, M. (2006). Comparing equilibrium real interest rates: Different approaches to understand Brazilian rates. Technical Report 101, Brazilian Central Bank.

Phelps, E. (1968). Money-wage dynamics and labor market equilibrium. Journal of Political Economy, 76:678-711.

Stock, J. \& Watson, M. (1998). Median unbiased estimation of coefficient variance in a time-varying parameter model. Journal of The American Statistical Association, 93:349-358.

Taylor, J. (1993). Discretion versus policy rules in practice. In Carnegie-Rochester Conference Series on Public Policy. Carnegie-Rochester.

Tejada, C. \& Portugal, M. (2002). Credibility and reputation: An application of the external circumstances model for the Real Plan. Revista Brasileira de Economia, 56(4):695-727.

Toledo, C. (2004). Ciclos do produto brasileiro: Decomposição e análise em “Tempo Real”. Technical report, FEA-USP, São Paulo.

Wicksell, K. (1936). Interest and Prices. Macmillan, London.

Woodford, M. (2003). Interest and Prices. Foundations of a Theory of Monetary Policy. Princeton University Press, Princeton. 